\title{
Life cycle, feeding and defecation patterns of Rhodnius ecuadoriensis (Lent \& León 1958) (Hemiptera: Reduviidae: Triatominae) under laboratory conditions
}

\author{
Anita G Villacís , Laura Arcos-Terán¹, Mario J Grijalva/+ \\ Center for Infectious Disease Research, School of Biological Sciences, Pontifical Catholic University of Ecuador, Quito, Ecuador ${ }^{1}$ Biomedi- \\ cal Sciences Department, Tropical Disease Institute, Ohio University, College of Osteopathic Medicine, Athens, OH 45701, USA
}

Rhodnius ecuadoriensis is the second most important vector of Chagas Disease (CD) in Ecuador. The objective of this study was to describe (and compare) the life cycle, the feeding and defecation patterns under laboratory conditions of two populations of this specie [from the provinces of Manabi (Coastal region) and Loja (Andean region)]. Egg-to-adult $(n=57)$ development took an average of $189.9 \pm 20$ (Manabi) and $181.3 \pm 6.4$ days (Loja). Mortality rates were high among Lojan nymphs. Pre-feeding time (from contact with host to feeding initiation) ranged from 4 min $42 \mathrm{~s}$ [nymph I (NI)] to 8 min $30 \mathrm{~s}$ (male); feeding time ranged from 14 min $45 \mathrm{~s}$ (NI)-28 min $25 \mathrm{~s}$ (male) (Manabi) and from 15 min $25 \mathrm{~s}$ (NI)-28 min $57 \mathrm{~s}$ (nymph V) (Loja). The amount of blood ingested increased significantly with instar and was larger for Manabi specimens $(p<0.001)$. Defecation while feeding was observed in Manabi specimens from stage nymph III and in Lojan bugs from stage nymph IV. There was a gradual, age-related increase in the frequency of this behaviour in both populations. Our results suggest that R. ecuadoriensis has the bionomic traits of an efficient vector of Trypanosoma cruzi. Together with previous data on the capacity of this species to infest rural households, these results indicate that control of synanthropic R. ecuadoriensis populations in the coastal and Andean regions may have a significant impact for CD control in Ecuador and Northern Peru.

Key words: Chagas disease - Rhodnius ecuadoriensis - life cycle - feeding and defecation patterns - Ecuador

Chagas Disease (CD) is one of the most serious health problems in Latin America (Schofield et al. 2006) where it affects an estimated eight million people with 108 million at risk of contracting its causative agent, Trypanosoma cruzi (Chagas 1909) (PAHO 2006). In Ecuador, an estimated 230,000 people are infected and 6.2 million are at risk of infection (PAHO 2006). Members of the subfamily Triatomine (Hemiptera: Reduviidae) serve as vectors and are responsible for $80-90 \%$ of new human infections in endemic areas (WHO 2002). Female Triatomines deposit eggs which after eclosion develop through five nymphal stages (NI-NV) and then later proceed to adults. Recent research has documented high domiciliary and peridomiciliary infestation with triatomines (Grijalva et al. 2005) and high anti-T. cruzi seroprevalence among the population (Grijalva et al. 2003, Black et al. 2007) prompting the initiation of a National Chagas Control Program in Ecuador, within the context of the Initiative of the Andean Countries for Chagas disease control (Schofield et al. 2006).

\footnotetext{
Financial support: UNICEF/UNDP/World Bank/WHO Special programme for Research and TDR/RCG, PLAN Internacional Ecuador, Ohio University, Pontifical Catholic University of Ecuador (PUCE) and the Ecuadorian Ministry of Health through the National Chagas Control Program

+ Corresponding author: grijalva@oucom.ohiou.edu

Received 5 June 2008

Accepted 10 October 2008
}

Rhodnius ecuadoriensis is considered the second most important vector of CD in Ecuador (Aguilar et al. 1999, Abad-Franch et al. 2001b, 2002, Grijalva et al. 2005). Populations of $R$. ecuadoriensis are widely distributed in the Ecuadorian Central and Southern coastal regions and the Southern Andean region of Ecuador and Northern Peru (Abad-Franch et al. 2002). In the coastal region, it is usually found in association with Phytelephas aequatorialis (Spruce 1869), an endemic palm species. These palms are very abundant in Manabí and Santo Domingo de los Tsachilas province, where the leaves are used widely for the construction of thatch roofs and the nuts for handcrafts and button manufacturing (Henderson et al. 1995, Southgate 1997, Abad-Franch et al. 2005b). In this region there are frequent invasions and colonizations by $R$. ecuadoriensis in the peridomicile and domicile areas. $R$. ecuadoriensis is also frequently found in domiciliary and peridomiciliary habitats in El Oro, province where palm trees are less abundant, and also in Loja Province and Northern Peru, where palm trees are absent (AbadFranch et al. 2001a, b, Cuba Cuba et al. 2002). There are morphological differences among $R$. ecuadoriensis populations from different regions, especially regarding color and size (AG Villacis et al. unpublished observations), however molecular studies indicate that they are all one species (Abad-Franch \& Monteiro 2005a).

Despite its abundance, there have been few studies of $R$. ecuadoriensis and its epidemiologic significance in Ecuador and Peru. The first description of this species was made by Lent and León, in 1958 (Cuba Cuba et al. 2002). This was followed by a series of studies on its geographical distribution and synanthropic behaviour 
(Carcavallo et al. 1999, Abad-Franch et al. 2001b, Cuba Cuba et al. 2003, Grijalva et al. 2005, Chavez 2006). The objective of this study was to describe the life cycle, feeding and defecation pattern of R. ecuadoriensis in the laboratory and to examine possible differences between populations from Manabí and Loja provinces, as this information is needed to determine the organism's vectorial capacity (Perlowagora-Szumlewicz 1969, Soares et al. 2000) and priorize control activities.

\section{MATERIALS AND METHODS}

Study area - Specimens were collected from two rural localities in Manabí (San Gabriel) [S01.0127 ${ }^{\circ}$, W80.3792 ${ }^{\circ}, 56 \mathrm{~m}$ above sea level (masl)] and Quebrada de Maconta (S01.0448 ${ }^{\circ}$, W80.3587, 87 masl) and two localities in Loja [Algarrobillo (S4.160 ${ }^{\circ}$, W80.080 730 to 850 masl)] and Naranjo Dulce (S4.0788 ${ }^{\circ}$, W79.7009 ${ }^{\circ}$, 1.121-1.683 masl), which are located in two different regions in Ecuador. In fact, Manabí Province lies in the coastal plains of Western Ecuador and has an average annual rainfall of $563 \mathrm{~mm} /$ year, whereas Loja Province comprises an area of inter-Andean temperate valleys and has an average rainfall of $400 \mathrm{~mm} /$ year (INAMHI 2008).

Triatomine collection, maintenance and size measurement - Triatomines were collected in domiciliary and peridomiciliary habitats for $1 \mathrm{man} / \mathrm{h}$ as previously described (Grijalva et al. 2005). Microhabitat temperature and relative humidity $(\mathrm{RH})$ were measured (EXTECH Model 45320, Washington, USA). Collected insects were maintained under appropriate conditions (Liebert 2003, Richmond 2003) in the insectary at the Center for Infectious Disease Research, Catholic University in Quito. This facility is equipped with a "dual chamber incubator" where the original microhabitat temperature and humidity conditions of each province were replicated (Manabí, $27 \pm 5^{\circ} \mathrm{C}, 75 \pm 5 \% \mathrm{RH}$; Loja, $24 \pm 6^{\circ} \mathrm{C}, 70 \pm$ $5 \% \mathrm{RH}, 12 \mathrm{~h}$ photoperiod in both chambers). Measurements of body size of adult individuals were made with a digital caliper (Didimatic Caliper, Model CD-6"C, Mitutoyo, Kanagawa, Japan).

Life cycle - Eggs laid in the laboratory were grouped by the oviposition date to initiate a cohort of 57 individuals per province. After eclosion, the insects from NI were separated individually into ventilated screw cap vials containing folded filter paper for support as well as a dead adult as source for endosymbionts (Huerta-Nuñez et al. 2006). Nymphs were offered the blood of anesthetized laboratory mice (Swiss) as a meal every day after eclosion and weekly after their first meal. Vials were checked daily for the presence of exuviae which are indicative of a molt. The number of days to complete each instar was recorded.

Feeding and defecation patterns - For each province, 240 individuals of $R$. ecuadorensis in different stages were observed. Respectively, 20 female and 20 male adults were analyzed as well as 40 R. ecuadorensis nymphs in each of the five stages. The triatomines were fed on restrained and anesthetized Swiss mice. Blood was offered daily to NI until they took their first meal; afterwards, blood was offered on a weekly basis for a period of $15 \mathrm{~min}$. We measured: (a) pre-feeding time (from contact with the host to insertion of the bug mouthparts into the host skin); (b) feeding interval (from feeding initiation to withdrawal of mouthparts from the host); and (c) defecation interval (from feeding initiation to first defecation. The triatomines were weighted $(\mathrm{mg})$ individually with an analytical balance (Mettler Toledo AB54-S, Switzerland) before and after each meal.

Statistical analyses - Descriptive statistics were calculated for all variables. Percent mortality was calculated based on insect deaths per stage/initial number of individuals in the cohort. Binomial tests were used to compare the defecation interval between the individuals from the two provinces. Spearman correlation coefficient was used to determine the relationship between the size of the body and blood meal in each of the adult and nymph stages so that the relationship between the length of the body in comparison with the duration of the life cycle in each province can be analyzed. The Mann Whitney $U$ test was used to compare the size of the blood meal (mg) in each stage and between both provinces. Finally, the independent $t$ test was used to analyze relationships in the total body length between females and males of both provinces.

\section{RESULTS}

Total body length - Measurements of body length in adult individuals from Loja and Manabí showed statistically significant differences (Manabí: male 13.82 $\pm 0.36 \mathrm{~mm}$, female $16.59 \pm 0.32 \mathrm{~mm}$; Loja: male 12.53 $\pm 0.33 \mathrm{~mm}$, females $14.72 \pm 0.39 \mathrm{~mm}, \mathrm{p}<0.05$ ).

Life cycle - Twenty six of 57 individuals from the Manabí cohort completed their development, in contrast to only three of the 57 individuals from the Loja cohort. The reasons for the high mortality in the later group are unknown. The average time it took an egg to develop into an adult in Manabí and Loja were $189.9 \pm 20$ and $181.3 \pm 6.4$ days, respectively (Table I). There was no statistical difference in times of development within each stage between Manabí and Loja cohorts ( $p>0.05)$. There was no correlation in either province between the total body length of the individuals and with their time of development ( $\mathrm{p}>0.05)$.

Feeding required for molting - In individuals from both provinces, at least one blood meal was needed for each stage to molt to the next. However, some individuals from Manabí $(\mathrm{NI}=12.3 \%$; NII $=4.2 \%)$ and from Loja (NI $=19.3 \%$; NII $=3.6 \%$; NIII $=28.6 \%$; NV $=10 \%$ ) required more than one blood meal to molt. In all individuals that required more than one blood meal, the initial blood meal was markedly smaller than the average for that stage (data not shown). These individuals (that had smaller blood meals) did not defecate within one and a half hours after initiation of the feeding.

Feeding habits - Fourty individuals of each NI and 20 for adult males and females were studied. The time it took for the insects to insert their mouth parts and start feeding ranged from $4 \min 42 \mathrm{~s}(\mathrm{NI})-8 \min 30 \mathrm{~s}$ 
(adult male) (Table II and III). This behavior was similar in individuals from both provinces. The feeding interval ranged from 14 min $45 \mathrm{~s}(\mathrm{NI})-28$ min $25 \mathrm{~s}$ (male) in Manabí and from $15 \min 25 \mathrm{~s}(\mathrm{NI})-28 \min 57 \mathrm{~s}(\mathrm{NV})$ in Loja. The size of the blood meal varied considerably from stage to stage, being the highest in NV (Table II and III). There was a significant difference in blood meal size between each NI and between both provinces $(\mathrm{p}<$ 0.01 ), being higher in Manabí, which correlated with the larger body size at each stage $(\mathrm{p}<0.05)$ presented by individuals from this province. The exception to this were 3rd instar and adult female individuals from Loja and Manabí which took blood meals of similar size $(\mathrm{p}=0.419$ and $\mathrm{p}=0.213$, respectively).

TABLE I

Duration of life cycle and mortality rates of Rhodnius ecuadoriensis from Manabí and Loja provinces maintained under laboratory conditions

\begin{tabular}{|c|c|c|c|c|c|c|c|c|c|c|c|c|}
\hline \multirow{3}{*}{$\begin{array}{l}\text { Developmental } \\
\text { stages }\end{array}$} & \multicolumn{6}{|c|}{ Manabí } & \multicolumn{6}{|c|}{ Loja } \\
\hline & \multicolumn{5}{|c|}{ Range (days) } & \multirow{2}{*}{$\begin{array}{c}\text { Mortality } \\
\%\end{array}$} & \multicolumn{5}{|c|}{ Range (days) } & \multirow{2}{*}{$\begin{array}{c}\text { Mortality } \\
\%\end{array}$} \\
\hline & $\mathrm{N}$ & Min & Max & Mean \pm SD & Median & & $\mathrm{N}$ & Min & Max & Mean \pm SD & Median & \\
\hline Egg - NI & 57 & 12 & 19 & $15.1 \pm 1.3$ & 15 & - & 57 & 10 & 22 & $13.1 \pm 1.7$ & 13 & - \\
\hline NI - NII & 48 & 24 & 55 & $28.3 \pm 6.7$ & 26 & 15.8 & 28 & 10 & 61 & $26.4 \pm 13.1$ & 20 & 50.9 \\
\hline NII - NIII & 34 & 25 & 71 & $34.9 \pm 11.3$ & 31 & 24.6 & 14 & 20 & 55 & $33.6 \pm 10.6$ & 33 & 24.6 \\
\hline NIII - NIV & 28 & 23 & 73 & $41.6 \pm 14.5$ & 39.5 & 10.5 & 10 & 21 & 54 & $34.0 \pm 11.9$ & 31 & 7.0 \\
\hline NIV - NV & 26 & 19 & 59 & $36.4 \pm 11.4$ & 34.5 & 3.5 & 6 & 17 & 48 & $36.3 \pm 10.7$ & 38 & 7.0 \\
\hline NV- Adult & 26 & 33 & 48 & $37.2 \pm 4.9$ & 36 & 0 & 3 & 24 & 51 & $37.7 \pm 13.5$ & 38 & 5.3 \\
\hline Total & 26 & 156 & 225 & $189.9 \pm 20$ & 195 & 54.4 & 3 & 181 & 193 & $181.3 \pm 6.4$ & 191 & 98.7 \\
\hline
\end{tabular}

$\mathrm{N}$ : number of individuals; mortality expressed as number of individuals dead divided by initial number of individuals in the cohort.

TABLE II

Feeding patterns of Rhodnius ecuadoriensis specimens from Manabí under laboratory conditions

\begin{tabular}{|c|c|c|c|c|c|c|c|}
\hline Stages & $\mathrm{N}$ & $\begin{array}{l}\text { Weight before } \\
\text { feeding }^{a}(\mathrm{mg})\end{array}$ & Feeding time (min) & $\begin{array}{l}\text { Weight after } \\
\text { feeding }^{b}(\mathrm{mg})\end{array}$ & Size of ingest ${ }^{c}(\mathrm{mg})$ & $\begin{array}{l}\text { Times its weight } \\
\text { increment }^{d}\end{array}$ & $\begin{array}{l}\text { Time to insert } \\
\text { the rostrumt } \\
\text { (min) }\end{array}$ \\
\hline $\mathrm{NI}$ & 40 & $0.2 \pm 0.08$ & $14^{\prime} 45^{\prime \prime} \pm 33^{\prime} 33^{\prime \prime}$ & $3.1 \pm 0.78$ & $2.8 \pm 0.70$ & $16.04 \pm 8.30$ & $4{ }^{\prime} 42^{\prime \prime} \pm 2{ }^{\prime} 55^{\prime \prime}$ \\
\hline NII & 40 & $1.79 \pm 0.34$ & $19^{\prime} 50^{\prime \prime} \pm 5{ }^{\prime} 30^{\prime \prime}$ & $12.49 \pm 1.15$ & $10.69 \pm 0.81$ & $7.23 \pm 1.66$ & $6{ }^{\prime} 25^{\prime \prime} \pm 3^{\prime} 59^{\prime \prime}$ \\
\hline NIII & 40 & $3.85 \pm 0.82$ & $22^{\prime} 48^{\prime \prime} \pm 4^{\prime} 12^{\prime \prime}$ & $26.25 \pm 6.34$ & $22.40 \pm 5.81$ & $6.91 \pm 1.28$ & $7 ' 05 "$ " $\pm 27^{\prime \prime}$ \\
\hline NIV & 40 & $9.97 \pm 1.57$ & $23^{\prime} 51^{\prime \prime} \pm 3^{\prime} 15^{\prime \prime}$ & $78.86 \pm 16.29$ & $68.89 \pm 16.12$ & $8.06 \pm 1.89$ & $7^{\prime} 17^{\prime \prime} \pm 2{ }^{\prime} 81^{\prime \prime}$ \\
\hline $\mathrm{NV}$ & 40 & $24.31 \pm 3.21$ & $24^{\prime} 19^{\prime \prime} \pm 11^{\prime} 57^{\prime \prime}$ & $154.19 \pm 46.30$ & $129.88 \pm 46.32$ & $6.43 \pm 2.04$ & $7 ' 35 " \pm 2{ }^{\prime} 97^{\prime \prime}$ \\
\hline Adult $\not$ & 20 & $58.64 \pm 5.44$ & $24^{\prime} 02^{\prime \prime} \pm 5^{\prime} 26^{\prime \prime}$ & $124.01 \pm 21.63$ & $65.37 \pm 19.35$ & $2.11 \pm 0.32$ & $6{ }^{\prime} 37^{\prime \prime} \pm 3{ }^{\prime} 22^{\prime \prime}$ \\
\hline Adult $\hat{\sigma}$ & 20 & $41.63 \pm 4.89$ & $28^{\prime} 25^{\prime \prime} \pm 6^{\prime} 17^{\prime \prime}$ & $85.30 \pm 11.99$ & $43.68 \pm 14.50$ & $2.09 \pm 0.44$ & $80^{\prime} \prime \pm 2{ }^{\prime} 38^{\prime \prime}$ \\
\hline
\end{tabular}

$a$ : average of the weight of each stage before the blood meal; $b$ : average of the weight of each stage after the blood meal; $c$ : size of the blood meal; $d$ : how much the weight increased comparing with the initial weight.

TABLE III

Feeding patterns of Rhodnius ecuadoriensis specimens from Loja under laboratory conditions

\begin{tabular}{|c|c|c|c|c|c|c|c|}
\hline Stages & $\mathrm{N}$ & $\begin{array}{l}\text { Weight before } \\
\text { feeding }^{a}(\mathrm{mg})\end{array}$ & Feeding time (min) & $\begin{array}{l}\text { Weight after } \\
\text { feeding }^{b}(\mathrm{mg})\end{array}$ & Size of ingest ${ }^{c}(\mathrm{mg})$ & $\begin{array}{l}\text { Times its weight } \\
\text { increment }^{d}\end{array}$ & $\begin{array}{l}\text { Time to insert } \\
\text { the rostrumt } \\
\text { (min) }\end{array}$ \\
\hline NI & 40 & $0.11 \pm 0.08$ & $15^{\prime} 25^{\prime \prime} \pm 4{ }^{\prime} 28^{\prime \prime}$ & $2.32 \pm 0.40$ & $2.22 \pm 0.40$ & $22.64 \pm 4.63$ & 4'52" \pm 2'05" \\
\hline NII & 40 & $1.25 \pm 0.26$ & $21^{\prime} 50 " \pm 4{ }^{\prime} 39^{\prime \prime}$ & $7.81 \pm 1.49$ & $6.50 \pm 1.48$ & $6.50 \pm 1.83$ & 7'42" \pm 3'05" \\
\hline NIII & 40 & $3.92 \pm 0.88$ & $25^{\prime} 30^{\prime \prime} \pm 4{ }^{\prime} 31^{\prime \prime}$ & $25.04 \pm 6.20$ & $21.12 \pm 6.29$ & $6.75 \pm 2.27$ & 9’16” \pm 2’48” \\
\hline NIV & 40 & $9.47 \pm 1.43$ & $26^{\prime} 41^{\prime \prime} \pm 4{ }^{\prime} 11^{\prime \prime}$ & $66.36 \pm 17.60$ & $56.90 \pm 17.53$ & $7.15 \pm 2.11$ & 8'07” \pm 2’13” \\
\hline NV & 40 & $22.92 \pm 2.64$ & $28 ' 57^{\prime \prime} \pm 44^{\prime} 41^{\prime \prime}$ & $143.19 \pm 38.42$ & $120.59 \pm 30.29$ & $6.33 \pm 1.84$ & 7’28” \pm 2’49”' \\
\hline Adult ${ }_{+}$ & 20 & $32.57 \pm 6.92$ & $25^{\prime} 12^{\prime \prime} \pm 4{ }^{\prime} 56^{\prime \prime}$ & $88.15 \pm 15.42$ & $55.73 \pm 16.38$ & $2.84 \pm 0.81$ & 7’46" \\
\hline Adult $\hat{\sigma}$ & 20 & $21.58 \pm 4.34$ & $26{ }^{\prime} 23^{\prime \prime} \pm 5{ }^{\prime} 27^{\prime \prime}$ & $54.49 \pm 6.89$ & $32.92 \pm 7.42$ & $2.60 \pm 0.51$ & 8'00” \pm 3'43”' \\
\hline
\end{tabular}

$a$ : average of the weight of each stage before the blood meal; $b$ : average of the weight of each stage after the blood meal; $c$ : size of the blood; $d$ : how much the weight increased comparing with the initial weight. 
TABLE IV

Defecation dynamics of Rhodnius ecuadoriensis from Manabí and Loja under laboratory conditions (Mus musculus blood)

\begin{tabular}{|c|c|c|c|c|c|c|c|}
\hline \multirow[b]{2}{*}{ Stage } & \multirow[b]{2}{*}{$\mathrm{N}$} & \multicolumn{3}{|c|}{ Manabí } & \multicolumn{3}{|c|}{ Loja } \\
\hline & & $\begin{array}{l}\text { First defecation (min) } \\
\text { Mean } \pm \text { SD }\end{array}$ & $\begin{array}{c}\text { Defecation } \\
\text { during feeding } \\
\%\end{array}$ & $\begin{array}{c}\text { Defecation } \\
\text { after feeding } \\
\%\end{array}$ & $\begin{array}{l}\text { First defecation (min) } \\
\text { mean } \pm \mathrm{SD}\end{array}$ & $\begin{array}{c}\text { Defecation } \\
\text { during feeding } \\
\%\end{array}$ & $\begin{array}{c}\text { Defecation } \\
\text { after feeding } \\
\quad \%\end{array}$ \\
\hline NI & 40 & $59 ' 11^{\prime \prime} \pm 11^{\prime} 04 ”$ & 0 & 0 & $01 \mathrm{~h} 07^{\prime} \pm 10^{\prime} 55^{\prime \prime}$ & 0 & 0 \\
\hline NII & 40 & $46^{\prime} 28^{\prime \prime} \pm 99^{\prime} 19^{\prime \prime}$ & 0 & 37.5 & $46{ }^{\prime} 12^{\prime \prime} \pm$ 7’09”' & 0 & 15 \\
\hline NIII & 40 & $41^{\prime} 33^{\prime \prime} \pm 88^{\prime} 15^{\prime \prime}$ & 5 & 45 & $40^{\prime} 38^{\prime \prime} \pm 7^{\prime} 07^{\prime \prime}$ & 0 & 52.5 \\
\hline NIV & 40 & $37^{\prime} 23^{\prime \prime} \pm 52^{\prime \prime}$ & 27.5 & 85 & $36{ }^{\prime} 33^{\prime \prime} \pm$ 7'19”' & 12.5 & 80 \\
\hline NV & 40 & $36^{\prime} 25^{\prime \prime} \pm 4^{\prime} 08^{\prime \prime}$ & 45 & 92.5 & $31 ’ 37^{\prime \prime} \pm 7{ }^{\prime} 53^{\prime \prime}$ & 42.5 & 82.5 \\
\hline Adult + & 20 & $22^{\prime} 10^{\prime \prime} \pm 55^{\prime} 5^{\prime \prime}$ & 75 & 100 & $24^{\prime} 27^{\prime \prime} \pm$ 4'49”' & 55 & 100 \\
\hline Adult $\hat{\sigma}$ & 20 & $29^{\prime} 04^{\prime \prime} \pm 55^{\prime} 25^{\prime \prime}$ & 70 & 90 & $30 ' 59^{\prime \prime} \pm 8 ' 27 "$ & 55 & 85 \\
\hline Total & 240 & & & & & & \\
\hline
\end{tabular}

$a$ : defecation during 15 min after completion of feeding.

Defecation patterns - All NI from both provinces failed to defecate during feeding or $15 \mathrm{~min}$ after the meal. The average defecation time from the initiation of feeding ranged from $22 \mathrm{~min} 10 \mathrm{~s}$ in female adults to over $1 \mathrm{~h}$ in NI (Table IV). Nevertheless, in Manabí and Loja, the proportion of nymphs that defecated within $15 \mathrm{~min}$ from the initiation of feeding increased with developmental stage (Table IV). Importantly, defecation while feeding was observed in Manabí specimens starting in NIII and in Loja in NIV, and increased with developmental stage to reach $75 \%$ in adults from Manabí and $55 \%$ of adults from Loja. There were no significant differences in the time taken to feed or to defecate between individuals from both provinces $(p>0.05)$.

\section{DISCUSSION}

The understanding of the life cycle, feeding and defecation patterns of $R$. ecuadoriensis is critical to assess its vectorial capacity and to refine interventions aimed to eliminate domiciliary populations and control peridomiciliary populations in Ecuador.

Total body length - Individuals from Manabí were found to be longer than those from Loja. Although the two populations are from two geographically and climatically different regions of Ecuador, the size difference could be a consequence of the adaptation to life in the domiciliary/peridomiciliary (Loja) versus sylvatic and domiciliary/peridomiciliary (Manabí) habitats. Studies are underway using morphometric and molecular techniques to clarify this issue.

Life cycle - Since development and survival depends on meal availability, blood source and environmental conditions, the situation might be different in the wild (Zarate 1983, Schofield 1985, Cabello et al. 1987, Guarneri et al. 2000a, b, Martinez-Ibarra et al. 2003, Arévalo et al. 2007). In our study the use of laboratory mice facilitated the standardization of the conditions, but in the field $R$. ecuadoriensis is frequently found in high densities infesting chicken nests in the peridomicile in Loja and Manabí (Grijalva et al. 2005) and in lower den- sities in palm trees in Manabí where they feed mainly in rodent and bird nests (MJ Grijalva et al. unpublished observations). Previous studies about other Rhodnius species, such as Rhodnius colombiensis, and Rhodnius prolixus (Arévalo et al. 2007), have found shorter duration of the life cycle than shown in our data. These studies also found the highest mortality in the progression from the NI-NII instar (Guarneri et al. 2000a, b, MartinezIbarra et al. 2003). Although this mortality is consistent with our Manabí data, we found significant mortality in the all developmental stages of the Loja cohort. The fact that in this cohort more individuals had incomplete meals and required a second blood meal to progress to the next stage could be an indication of problems in the adaptation of this cohort to the feeding conditions in the laboratory, such as humidity and temperature, which could have caused the increased mortality. Da Silva and Da Silva (1989) demonstrated wide fluctuations on the duration of life cycles based on temperature changes for many species (Arévalo et al. 2007). One of these studies reports life cycle durations for $R$. ecuadoriensis of 141 days at $25^{\circ} \mathrm{C}$ and 120 days at $30^{\circ} \mathrm{C}$ (Silva \& Silva 1990) which is considerable shorter than our results $(189.9 \pm 20$ and $181.3 \pm 6.4$ days for Manabí and Loja, respectively). While we do not have an explanation for these differences, variability of life cycle duration depending on different laboratory conditions has been documented [101, 127 and 209 days from Rhodnius nasutus (Da Silva \& Da Silva 1989, Soares et al. 1995), 212 and 126 days for Rhodnius pallescens (Juberg \& Rangel 1984) and 144,4 days for R. colombiensis (Arévalo et al. 2007)].

Feeding patterns - Zeledon et al. (1977) indicated that prior to feeding the insects were in intimate contact with their prey for 5-10 min. This is consistent with our observations of the relatively long time it took for the bugs to start feeding after being placed on the host. Feeding interval ranged from 14-28 $\mathrm{min}$, which is consistent with findings in other species (Almeida et al. 2003). Most individuals in our study required only one blood meal to molt as has been reported for other species (Guarneri et al. 2000a). 
In all cases, the requirement for second blood meal was associated with a small blood meal ingested during the first feeding. As expected, size of the meal increased with developmental stage and was found to be the highest in NV. The size of the meal was larger in the Manabí cohort than in the Loja cohort, which correlated with the larger body size found in individuals from Manabí.

Defecation patters - Initial stages (NI and NII) of $R$. ecuadoriensis from both regions failed to defecate during feeding. However, prandial (during feeding) defecation increased with development reaching $75 \%$ and $55 \%$ in individuals from Manabí and Loja, respectively. Triatomines that defecate during that period, such as Triatoma infestans and $R$. prolixus are considered effective vectors of T. cruzi to humans (Pippin 1970, Zeledon et al. 1977, Bar et al. 2003, Salazar et al. 2005). Based on this, it could be hypothesized that $R$. ecuadoriensis is an effective T. cruzi vector. Moreover, since postprandial defecation started earlier in individuals from Manabí the vector competence of those might be higher than those from Loja. Similarly, a higher percentage of females than males from both provinces defecated during feeding or soon thereafter, with the feces being deposited on the skin, suggesting a higher vectorial competence of females over males as previously suggested (Rabinovich et al. 1979, Crocco \& Catalá 1996, Nogueda-Torres et al. 2000, Nattero et al. 2002).

R. ecuadoriensis is widely distributed in Manabí and Loja provinces. Rural communities in Loja present high domiciliary and peridomiciliary infestation, colonization and crowding indexes with $R$. ecuadoriensis (MJ Grijalva et al. 2005), and it is associated primarily with human habitats. On the other hand, there seems to be a high level of domiciliary and peridomiciliary infestation/ reinfestation with $R$. ecuadoriensis in Manabí province (MJ Grijalva et al. unpublished observatios), most likely from sylvatic habitats. These observations, coupled with the results from this study, which indicate a high vector capacity, suggest that control of this specie should be regarded as a priority in Ecuador.

\section{ACKNOWLEDGMENTS}

To Francisco Palomeque and Fernando Abad-Franch, for technical support, and to Mauricio S. Lascano and William S. Romoser, for revisions of this manuscript.

\section{REFERENCES}

Abad-Franch F, Aguilar HM, Paucar A, Lorosa ES, Noireau F 2002. Observations on the domestic ecology of Rhodnius ecuadoriensis, vector of Chagas disease in Ecuador. Mem Inst Oswaldo Cruz 97: 199-202.

Abad-Franch F, Monteiro FA 2005a. Molecular research and the control of Chagas disease vectors. An Acad Bras Cienc 77: 437-454.

Abad-Franch F, Palomeque FS, Aguilar HM 2001a. Control de la transmisión vectorial de la enfermedad de Chagas en el Ecuador. FASBASE, Ministerio de Salud Pública del Ecuador, Quito, 9 pp.

Abad-Franch F, Palomeque FS, Aguilar HM, Miles MA 2005b. Field ecology of sylvatic Rhodnius populations (Heteroptera, Triatominae): risk factors for palm tree infestation in western Ecuador. Trop Med Intl Health 10: 1258-1266.
Abad-Franch F, Paucar A, Carpio C, Cuba Cuba CA, Aguilar HM, Miles MA 2001b. Biogeography of Triatominae (Hemiptera: Reduviidae) in Ecuador: implications for the design of control strategies. Mem Inst Oswaldo Cruz 96: 611-620.

Aguilar HM, Abad-Franch F, Racines VJ, Paucar CA 1999. Epidemiology of Chagas disease in Ecuador. A brief review. Mem Inst Oswaldo Cruz 94: 387-393

Almeida CE, Fraischetti CN, Pacheco RS, Costa J 2003. Triatoma rubrovaria (Blanchard, 1843) (Hemiptera-Reduviidae- Triatominae) III: Patterns of feeding, defecation and resistance to starvation. Mem Inst Oswaldo Cruz 98: 367-371.

Arévalo A, Carranza JC, Guhl F, Clavijo JA, Vallejo GA 2007. Comparación del ciclo de vida de Rhodnius colombiensis Moreno, Jurberg \& Galvão, 1999 y Rhodnius prolixus Stal, 1872 (Hemiptera, Reduviidae, Triatominae) en condiciones de laboratorio. Biomédica 27: 119-129.

Bar ME, Milano AM, Damborsky F, Miryam P 2003. Feeding and defecation patterns in Triatoma rubrovaria (Heteroptera: Reduviidae) under laboratory conditions. Rev Soc Entomol Argent 62: 107-113.

Black CL, Ocaña S, Riner D, Costales JA, Lascano MS, Davila S, Arcos-Teran L, Seed RJ, Grijalva MJ 2007. Household risk factors for Trypanosoma cruzi seropositivity in two geographic regions of Ecuador. J Parasitol 93: 12-16.

CabelloDR,LizanoE,ValderramaA1987.EstadísticasvitalsdeRhodnius neivai Lent, 1953 (Hemiptera: Reduviidae) en condiciones experimentales. Mem Inst Oswaldo Cruz 82: 511-524.

Carcavallo RU, Curto de Casas SI, Sherlock IA, Galíndez Girón I, Jurberg J, Galvão C, Mena Segura CA, Noireau F 1999. Geographical distribution and alti-latitudinal dispersion. In RU Carcavallo, I Galíndez Girón, J Jurberg, H Lent (eds.), Atlas of Chagas Disease Vectors in the Americas, Vol. III, Fiocruz, Rio de Janeiro, p. 747-792.

Chagas C 1909. Nova tripanozomiaze humana. Estudos sobre a morfolojia e o ciclo evolutivo do Schizotrypanum cruzi n. gen, n. sp., ajente etiolojico de nova entidade morbida do homem. Mem Inst Oswaldo Cruz 1: 11-80.

Chavez J 2006. Contribution to the study of Triatominae in Peru: Geographic distribution, nomenclature and taxonomic notes. $A n$ Fac Med 67: 65-76.

Crocco LB, Catalá S 1996. Feeding and defecation pattern in Triatoma sordida. Mem Inst Oswaldo Cruz 91: 409-413.

Cuba Cuba CA, Abad-Franch F, Roldán RJ, Vargas VF, Pollack VL, Miles MA 2002. The triatomines of Northern Peru with emphasis on the ecology and infection by trypanosomes of Rhodnius ecuadoriensis (Triatominae). Mem Inst Oswaldo Cruz 97: 175-183.

Cuba Cuba CA, Vargas F, Roldán J 2003. Domestic Rhodnius ecuadoriensis (Hemiptera, Reduviidae) infestation in Northern Peru: a comparative trial of detection methods during a six-month follow-up. Rev Inst Med Trop Sao Paulo 45: 85-90.

Da Silva IG, Da Silva HH 1989. The influence of temperature on the biology of triatominae. IX. Rhodnius nasutus Stal, 1859 (Hemiptera, Reduviidae). Mem Inst Oswaldo Cruz 84: 377-382.

Grijalva MJ, Escalante L, Paredes RA, Costales JA, Padilla A, Rowland EC, Aguilar HM, Racine J 2003. Seroprevalence and risk factors for Trypanosoma cruzi infection in the Amazon region of Ecuador. Am J Trop Med and Hyg 69: 380-385.

Grijalva MJ, Palomeque-Rodriguez FS, Costales JA, Dávila S, ArcosTerán L 2005. High household infestation rates by synanthropic vectors of Chagas disease in Southern Ecuador. J Med Entomol 42: 68-74.

Guarneri AA, Diotaiuti L, Gontijo NF, Gontijo AF, Pereira MH $2000 \mathrm{~b}$. Comparison of feeding behavior of Triatoma infestans, Triatoma 
brasilensis, Triatoma sordida and Triatoma peseudomaculata (Heteroptera, Reduviidae). J Insect Physiol 46: 1121-1127.

Guarneri AA, Pereira MH, Diotaiuti L 2000a. Influence of the blood meal source on the development of Triatoma infestans, Triatoma brasilensis, Triatoma sordida and Triatoma pseudomaculata (Heteroptera, Reduviidae). J Med Entomol 37: 373-379.

Henderson A, Galeano G, Bernal R 1995. Field Guide to the Palms of the Americas. Princeton University Press, Princeton, 363 pp.

Huerta-Nuñez L, Martínez J, Alcocer RL, Ramsey JM, MartínezRomero E 2006. Diversidad de bacterias endosimbiontes de insectos de la subfamilia triatominae. Rev Latinoam Microbiol 48: 211-225.

INAMHI - Instituto Nacional de Meteorología en Hidrología 2008 Climatología: características generales del clima en el Ecuador. Available at http://www.inamhi.gov.ec.

Jurberg J, Rangel EF 1984. Ciclo biológico de Rhodnius pallescens Barber, 1932 (Hemiptera, Reduviidae, Triatominae) em laboratório. Mem Inst Oswaldo Cruz 79: 303-308.

Lent H, León LA 1958. Um novo Rhodnius Stäl do Ecuador (Hemiptera, Reduviidae). Rev Brasil Biol 18: 181-185.

Liebert MA 2003. Vector borne and zoonotic: arthropod containment levels (ACLs), Vol. 3, n 2. Mary AnnLiebert, Inc. Available athttp:// www.liebertonline.com/doi/pdf/10.1089/153036603322163475.

Martinez-Ibarra JA, López M, Hernández M, Grant Guillén Y 2003. Influence of the blood meal source on the biology of Meccus picturatus Usinger 1939 (Hemiptera: Reduviidae: Triatominae) under laboratory conditions. Mem Inst Oswaldo Cruz 98: 227-232.

Nattero JL, Crocco B, Rodriguez CS 2002. Feeding and defecation behaviour of Triatomapatagonica (Del Ponte, 1929) (Hemiptera: Reduviidae). Mem Inst Oswaldo Cruz 97: 1063-1065.

Nogueda-Torres B, Aguilar RA, Tornell LI, Camacho AD 2000. Defecation pattern in seven species of triatomines (Insecta, Reduviidae) present in México. Rev Latinoam Microbiol 42: 145-148.

PAHO - Pan American Health Organization 2006. Technical Report: Quantitative Chagas disease estimates. OPS/HDMCD/425-06, Montevideo, $28 \mathrm{pp}$.

Perlowagora-Szumlewicz A 1969. Estudos sobre a biologia do Triatoma infestans, o principal da doença de Chagas no Brasil (importância de algumas de suas características biológicas no planejamento de esquemas de combates a esse vetor). Rev Brasil Malariol Doen Trop 21: 117-159.

Pippin WE 1970. The biology and vector capability of Triatoma sanguisuga texana Usinger and Triatoma gerstaeckeri (Stal) compared with Rhodnius prolixus (Stal) (Hemiptera: Triatominae). J Med Entomol 7: 30-45.

Rabinovich JE, Leal JA, Feliciangeli de Piñero D 1979. Domiciliary biting frequency and bloodingestion of the Chagas' disease vector Rhodnius prolixus Stål (Hemiptera: Reduviidae) in Venezuela. Trans Roy Soc Trop Med Hyg 73: 272-283.

Richmond JY 2003. Anthology of Biosafety. VI. Arthropod-borne diseases. Mundelein IL: American Biological Safety Association. Available at http://www.bccdc.org/downloads/pdf/lab/reports/ annual_report_2003.pdf.

Salazar Schetino PM, de Haro Arteaga I, Bravo CM 2005. Importance of three vectors of Trypanosoma cruzi in Mexico. Medicina 65: 63-69.

Schofield CJ 1985. Population dynamics and control of Tríatoma infestans. Ann Soc Belg Med Trop 65: 149-64.

Schofield CJ, Jannin J, Salvatella R 2006. The future of Chagas disease control. Trends in Parasitology 22: 583-588.

Silva IG, Silva HH 1990. Influência da temperatura na biología de triatomíneos. XV. Rhodnius ecuadoriensis Lent e Léon, 1958. Rev Goiana Med 36: 49-54.

Soares MJ, dos Santos Filho PN, Bento DN 1995. The developmental cycle of Rhodnius nasutus Stal, 1859 studied in the laboratory. Rev Soc Bras Med Trop: 28: 113-116.

Soares RP, Evangelista LG, Laranja LS, Diotaiuti L 2000. Populations dynamics and feeding behaviour of Triatoma brasilensis and Triatoma pseudomaculata, main vectors of Chagas disease in Northeastern Brazil. Mem Inst Oswaldo Cruz 95: 151-155.

Southgate D 1997. Alternatives for habitat protection and rural income generation. Document ENV-107, The Inter-American Development Bank, Washington, DC, 54 pp.

Spruce RA 1869. Palmae Amazonicae, sive enumeratio palmarum in itinere suo per regiones Americas aequatoriales lectarum. J Linn Soc Bot 11: 65-183.

WHO - World Health Organization 2002. Control of Chagas' disease. Second report of the WHO Expert Committee, WHO, Genebra, 107 pp.

Zarate LG 1983. The biology and behavior of Triatoma barberi (Hemiptera: Reduviidae) in México. III. Completion of the life cycle adult longevity and egg production under optimal eeding conditions. J Med Entomol 20: 485-97.

Zeledón R, Alvarado R, Jirón JF 1977. Observations on the feeding and defecation patterns of three Triatominae species (Hemiptera:Reduviidae) Acta Trop 34: 65-77. 